\title{
Novel CD20 monoclonal antibodies for lymphoma therapy
}

\author{
Shundong Cang ${ }^{1}$, Nikhil Mukhi ${ }^{2}$ Kemeng Wang ${ }^{2}$ and Delong Liu $^{2 *}$
}

\begin{abstract}
Rituximab (RTX), a monoclonal antibody (mAb) against CD20, has been widely used for lymphoma therapy. RTX in combination with cyclophosphamide /doxorubicin /vincristine /prednisone (R-CHOP) remains the standard frontline regimen for diffuse large B-cell lymphoma. However, suboptimal response and /or resistance to rituximab have remained a challenge in the therapy of B-cell non-Hodgkin's lymphoma (NHL). Novel agents are under active clinical trials. This review will summarize the latest development in new mAbs against CD20, which include second-generation mAbs, ofatumumab, veltuzumab (IMMU-106), ocrelizumab (PRO70769), and third-generation mAbs, AME-133v (ocaratuzumab), PRO131921 and GA101 (obinutumumab).
\end{abstract}

\section{Background}

Rituximab (RTX), a monoclonal antibody (mAb) against CD20, has been widely used for lymphoma therapy [1-4]. RTX in combination with cyclophosphamide/doxorubicin/vincristine/prednisone (R-CHOP) remains the standard frontline regimen for diffuse large B-cell lymphoma (DLBCL) [5,6]. However, suboptimal response and /or resistance to rituximab have remained a challenge in the therapy of B-cell non-Hodgkin's lymphoma (NHL). Novel agents are under active clinical trials. This review will summarize the latest development in new mAbs against CD20.

\section{Rituximab, the first-generation CD20 monoclonal antibody}

CD20 is the first B-cell specific antigen defined by the monoclonal antibody tositumomab $[7,8]$. Human CD20 is encoded by the gene MS4A1 gene located on chromosome 11q12.2 [9]. CD20 molecule is a 297 amino acid phosphoprotein with four transmembrane domains (Figure 1). It plays a critical role in B-cell development. CD20 has been a superb biomarker for immunotherapies targeting B-cell derived diseases [10]. It is known to function through binding to Src family tyrosine kinases, such as Lyn, Fyn, and Lck, and believed to be involved as a result in phosphorylation cascade of intracellular

\footnotetext{
* Correspondence: delong_liu@nymc.edu

2Department of Medicine, New York Medical College and Westchester Medical Center, Valhalla, NY 10595, USA

Full list of author information is available at the end of the article
}

proteins. It is a tetra-transmembrane protein that essentially remains on the membrane of B cells without dissociation or internalization upon antibody binding (Figure 2) [11]. RTX, the first generation CD20 mAb, can induce complement-dependent cytotoxicity (CDC) and antibody-dependent cellular cytotoxicity (ADCC), leading to its clinical activity against lymphoma cells [12]. CDC represents the primary mechanism for cellkilling by RTX. However, some lymphoid cells ( i.e. 10\% of CLL cells) were resistant to CDC because of lower levels of complement activation or decreased cytotoxicity of activated complements. In addition, RTX can lead to apoptosis of B cells upon binding to CD20 and therefore can directly inhibit cell growth [13]. Recently, a novel mechanism of cell killing by mAbs was reported to involve reactive oxygen species mediated through NADPH [14].

RTX has been widely used for lymphoma therapy [1-4,15-17]. R-CHOP chemotherapy remains the standard regimen for newly diagnosed DLBCL [3,5,18]. CD20 mAbs conjugated to nuclear isotopes have also been approved for lymphoma therapy [18-22]. RTX has also been studied in new combination regimens, particularly for relapsed and refractory lymphomas [23-31].

To increase antitumor activity and Fc binding affinity for the low-affinity FcyRIIIa receptor (CD16) on immune effector cells, new generations of anti-CD20 monoclonal antibodies (mAbs) are being developed $[7,8,11]$. 


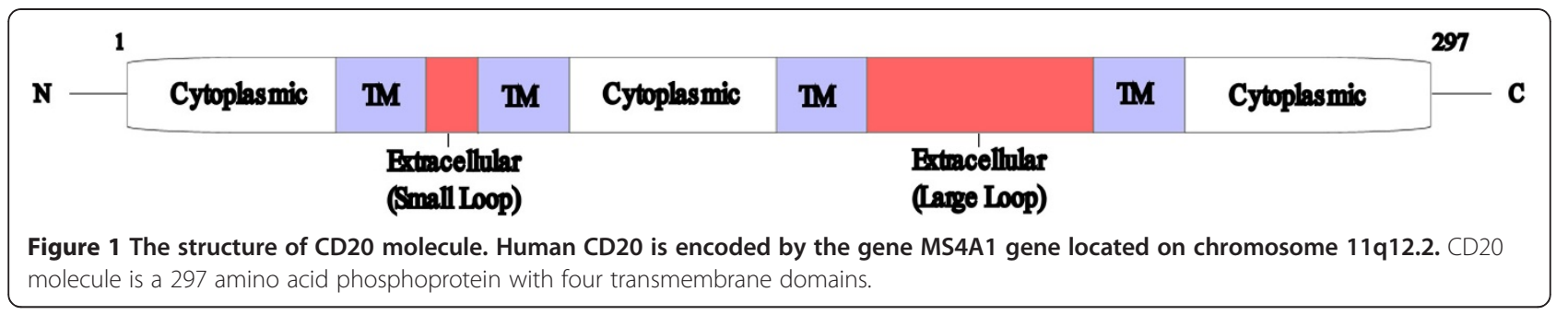

\section{Second-generation anti-CD20 mAbs}

The second-generation anti-CD20 mAbs include ofatumumab, veltuzumab, and ocrelizumab. These are humanized to reduce immunogenicity.

Ofatumumab (OFA) is a fully human type I anti-CD20 IgG1kappa mAb [15,32-37]. Ofatumumab binds to both the small and large extracellular loops (ECL) of CD20 molecule, and is more effective than rituximab at killing target cells. It has been shown to be more potent than RTX against both RTX- sensitive and resistant cells [38]. Its activity against RTX-resistant cells and the potent CDC effect are believed to be due to the proximal epitope of the small loop of CD20 molecule and the high capacity for $\mathrm{C} 1 \mathrm{q}$ activation.
OFA (arzerra) has been approved for treatment of relapsed or refractory CLL who have failed fludarabine and alemtuzumab (FA-ref) [39]. OFA is given IV weekly on a fixed dose, $300 \mathrm{mg}$ for dose 1, and $2000 \mathrm{mg}$ weekly $\mathrm{x} 7$ in subsequent doses. This is followed by every four weeks for 4 more doses [36]. In FA-ref CLL patients, the response rate was $58 \%$. OFA was also studied in 116 patients with RTX-refractory follicular lymphoma (FL) [40]. These patients received 8 weekly infusions (dose 1, $300 \mathrm{mg}$ and doses 2-8, 500 or 1000 $\mathrm{mg}$ ). The median age was 61 years, and the median number of prior therapies was 4 . The overall response rate (ORR) was $13 \%$ and $10 \%$ for the 500 -mg and 1000 mg arms, respectively (Table 1 ). The median PFS was

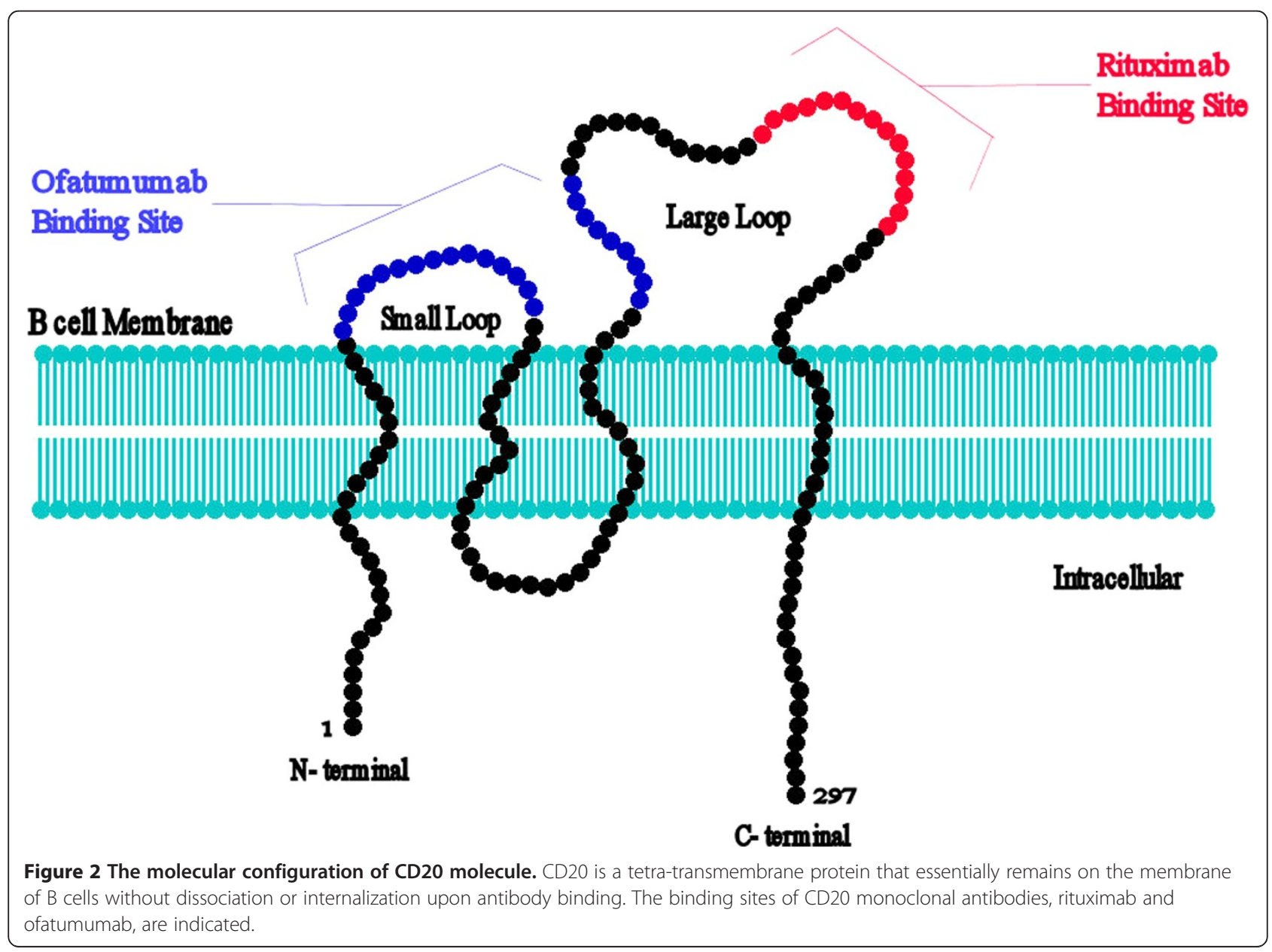


Table 1 Second generation CD20 monoclonal antibodies

\begin{tabular}{|c|c|c|c|c|c|c|}
\hline Monoclonal Ab & Ig type & Patients & Regimen & $\begin{array}{l}\text { Overall response } \\
\text { rate(\%) }\end{array}$ & Adverse events & Reference \\
\hline \multirow[t]{3}{*}{$\begin{array}{l}\text { Ofatumumab } \\
\text { (OFA) }\end{array}$} & IgG1 Kappa & 116 & $\begin{array}{l}\text { Ofatumumab (Refractory FL) } \\
500 \text { mg 1000mg }\end{array}$ & $13 \% 10 \%$ & $\begin{array}{l}\text { Infections, rash, urticaria, pruritis, } \\
\text { neutropenia, anemia, } \\
\text { thrombocytopenia }\end{array}$ & {$[40]$} \\
\hline & & 59 & $\begin{array}{l}\text { O-CHOP (untreated FL) } \\
500 \mathrm{mg} 1000 \mathrm{mg}\end{array}$ & $90 \% 100 \%$ & Leucopenia, neutropenia & [41] \\
\hline & & 61 & $\begin{array}{l}\text { O-FC (Frontline therapy for CLL) } \\
500 \text { mg } 1000 \text { mg }\end{array}$ & $77 \% 73 \%$ & $\begin{array}{l}\text { Neutropenia, thrombocytopenia, } \\
\text { anemia, infection }\end{array}$ & {$[35]$} \\
\hline Veltuzumab & $\operatorname{lgG} 1$ & 82 & $\begin{array}{l}\text { Veltuzumab (Relapsed/refractory B } \\
\text { cell NHL) } 80 \text { to } 750 \mathrm{mg} / \mathrm{m}^{2}\end{array}$ & $\begin{array}{l}44 \%(F L) 83 \% \\
\text { (MZL) } 43 \%(D L B L)\end{array}$ & $\begin{array}{l}\text { Fatigue, pruritis, asthenia, fever, } \\
\text { dyspnea, headache, infection }\end{array}$ & {$[42]$} \\
\hline Ocrelizumab & $\lg G 1$ & 47 & $\begin{array}{l}\text { Ocelizumab (Relapsed/Refractory FL) } \\
750 \mathrm{mg} / \mathrm{m}^{2}\end{array}$ & $38 \%$ & $\begin{array}{l}\text { Infusion related reaction, } \\
\text { nasopharyngitis, asthenia, } \\
\text { lymphopenia, infection }\end{array}$ & {$[43]$} \\
\hline
\end{tabular}

Abbreviations: DLBCL: diffuse large B cell lymphoma; FL: follicular lymphoma; MZL: marginal zone lymphoma; NHL: non-Hodgkin lymphoma.

5.8 months. Infections, rash, urticaria, fatigue, and pruritus were the most common adverse events. Severe adverse events included neutropenia, anemia, and thrombocytopenia in a subset of patients.

OFA is being explored in combination with other agents in various B-cell neoplasms. An international, phase II trial was conducted to assess two doses of ofatumumab combined with $\mathrm{CHOP}$ (O-CHOP) for frontline treatment for follicular lymphoma [41]. The study randomized 59 patients to receive either OFA $500 \mathrm{mg}(\mathrm{n}=29)$ or $1000 \mathrm{mg}(\mathrm{n}=30)$ on day 1 , with CHOP on day 3 every 3 weeks for six cycles. ORR was $90 \%$ for the 500-mg group and $100 \%$ for the 1000-mg group (Table 1). CR/CRu was $62 \%$. The most common severe adverse events were leucopenia (29\%) and neutropenia (22\%). O-CHOP was reported to be safe and effective as frontline therapy for $\mathrm{FL}$ patients.

Another international randomized phase II trial was done using OFA in combination with fludarabine 25 $\mathrm{mg} / \mathrm{m}^{2}$ and cyclophosphamide $250 \mathrm{mg} / \mathrm{m}^{2}$ on days $2-4$ in course 1 and on days $1-3$ for courses 2-6 [35]. This was repeated every 4 weeks for 6 courses. Two OFA dose levels, $500 \mathrm{mg}(\mathrm{n}=31)$ or $1000 \mathrm{mg}(\mathrm{n}=30)$, were given to patients with untreated CLL after randomization. The first OFA dose was $300 \mathrm{mg}$ for both cohorts. The median age of the study pts was 56 years; 17 p deletion was seen in $13 \%$ of patients. CR rate was $32 \%$ for the $500-\mathrm{mg}$ and $50 \%$ for the $1000-\mathrm{mg}$ cohort. ORR was $77 \%$ and $73 \%$, respectively. Beta 2 -microglobulin and the number of O-FC courses given correlated significantly with CR, ORR, PFS, according to univariate analyses $(\mathrm{P}<.05)$. Neutropenia $(48 \%)$, thrombocytopenia (15\%), anemia (13\%), and infection (8\%) were found to be the most common severe adverse events. The study concluded that O-FC is active and safe in treatment-naive CLL patients, including high-risk patients with $17 \mathrm{p}$ deletion.
Veltuzumab (IMMU-106, hA20) has more potent binding avidities and a stronger effect on CDC than rituximab [44]. Veltuzumab is a humanized, type I antiCD20 IgG1 mAb, engineered recombinantly with complementarity-determining regions (CDRs) identical to rituximab, except for a single amino acid change, Asp101 instead of Asn101, in the CDR3 of the variable heavy chain $[10,44]$. This modification results in significantly slower off-rates and increased CDC cytotoxicity in three human lymphoma cell lines. Clinically, veltuzumab has been studied in over 150 patients with lymphomas and autoimmune diseases. In a multicenter phase I/II dose-finding study of veltuzumab in relapsed/ refractory B-cell non-Hodgkin's lymphoma (NHL), eighty-two patients (median age, 64 years; 79\% stage III/ IV, one to nine prior treatments) received infusions of $80-750 \mathrm{mg} / \mathrm{m}^{2}$ once-weekly for four doses, with no grade 3 to 4 drug-related adverse events other than infusion-related reactions [42]. Complete response (CR) was seen in $27 \%$ of FL patients despite failure of two to five prior rituximab-containing regimens. ORR for FL, MZL, and DLBCL was $44 \%, 83 \%$, and $43 \%$, respectively (table 1). The median duration of responses was 19.7 months. B cell depletion was seen at all dose levels studied. The depletion occurred after the first infusion. The veltuzumab serum half-lives were similar after the fourth infusion, and mean antibody serum levels were higher than the values generally considered important for antiCD20 therapy (i.e., $25 \mathrm{mg} / \mathrm{ml}$ ). Subcutaneous injections of low doses ( $80-320 \mathrm{mg}$ ) were also studied and have also proved to be safe and pharmacologically active [45].

Ocrelizumab (PRO70769) is another type I second generation humanized $\mathrm{mAb}$ that differs from rituximab at several amino acid positions within the CDRs of the light chain and heavy chain variable regions. With enhanced efficacy toward lymphoid malignancies and increased binding affinity for the low-affinity variants of the FcrRIIIa receptor (CD16), this mAb has increased 
$\mathrm{ADCC}$ and lower $\mathrm{CDC}$ activity compared with rituximab. This mAb has been evaluated in a phase I/II study for safety and efficacy in patients with relapsed/ refractory follicular lymphoma (FL) after failing prior RTX therapy [43]. Forty-seven patients were enrolled in three dose cohorts and received eight infusions every 3 weeks: cohort $\mathrm{A}, 200 \mathrm{mg} / \mathrm{m}^{2}(\mathrm{n}=15)$; cohort $\mathrm{B}$, $375 \mathrm{mg} / \mathrm{m}^{2}(\mathrm{n}=16)$; cohort $\mathrm{C}$, first dose $375 \mathrm{mg} / \mathrm{m}^{2}$ with seven subsequent doses at $750 \mathrm{mg} / \mathrm{m}^{2}(\mathrm{n}=16)$. The patients had a median age of 58 years and had received a median of 2 (range $1-6$ ) prior regimens. The grade $3 / 4$ toxicity occurred in $9 \%$ of patients. The most common toxicity was infusion-related reactions which occurred in $74 \%$ of the patients. The ORR was $38 \%$ regardless of affinity variants in the FcyRIIIa. The median follow-up was approximately 28 months, and the median PFS was 11.4 months.

\section{Third-generation anti-CD20 mAbs}

The third-generation humanized CD-20 mAbs have an engineered Fc region to increase their binding affinity for the Fc $\gamma$ RIIIa receptor. Three third-generation mAbs, AME-133v, PRO131921 and GA101, are undergoing active clinical development.

AME-133v (LY2469298, ocaratuzumab) is a type I, humanized IgG1 mAb. Its binding affinity to CD20 has a 13 to 20- fold increase with 5 to 7 - fold higher avidity to the low-affinity (F/F and F/V) variants of Fc $\gamma$ RIIIa receptor. These may have been the mechanisms to overcome the lower response rates and shorter duration of responses to rituximab. A phase I study was done with dose escalation in 10 Japanese patients with relapsed and /or refractory FL. It was administered by intravenous infusion at 100 or $375 \mathrm{mg} / \mathrm{m}^{2}$ weekly for 4 weeks. Nine patients were F-carriers while one was homozygous for valine $(\mathrm{V} / \mathrm{V})$ at position 158 of FcyRIIIa. There were no dose-limiting toxicities. Five (50\%) of ten patients responded to ocaratuzumab treatment (three $\mathrm{CR}$, one unconfirmed $\mathrm{CR}$ and one partial response).
Ocaratuzumab was well tolerated and clinical activity was observed in FL patients pretreated with rituximab, mostly consisting of F-carriers [46]. Another phase I dose escalation study from US has also been reported in 23 relapsed FL patients. The dosages were well tolerated from 2 up to $375 \mathrm{mg} / \mathrm{m}^{2}$ [47]. This highest dose was used in a phase II trial in 44 patients with relapsed FL following prior rituximab[48]. These patients with the low-affinity FcyRIIIa polymorphism (F-carriers) received $375 \mathrm{mg} / \mathrm{m}^{2}$ of ocaratuzumab weekly for 4 doses. The ORR was $36 \%$ and median progression free survival (PFS) reached 91 weeks (Table 2). In this analysis, there were 56 patients who received 100 and $375 \mathrm{mg} / \mathrm{m}^{2}$ of ocaratuzumab. Eight of these patients had a median of 2 prior rituximab treatments (range 1-6). Five of the 8 patients showed a longer PFS after ocaratuzumab administration, compared with last rituximab treatment. These 5 patients had the F/F low-affinity genotype of FcyRIIIa. Three of the patients had prolonged remission [48]. Ocaratuzumab will need to be compared to rituximab in randomized clinical trials to substantiate its potential clinical advantages.

PRO131921 is another humanized anti-CD20 mAb recombinantly engineered for enhanced $\mathrm{CDC}$ and ADCC activities over RTX $[15,52,53]$. In preclinical in vivo studies, it was shown to have better anti-tumor efficacy than rituximab. PRO131921 was given to patients (pts) with relapsed and /or refractory indolent lymphoma who failed rituximab-containing regimen [51]. This phase I study determined the maximum tolerated dose (MTD) and the pharmacokinetics (PK). PRO131921 was infused weekly for 4 weeks on days 1,8 , 15 and 22. The dose of the first infusion was half of subsequent infusions. Twenty-four pts were treated with PRO131921 at doses escalated from $25 \mathrm{mg} / \mathrm{m}^{2}$ to 800 $\mathrm{mg} / \mathrm{m}^{2}$. A median of 2 (range 1-6) prior regimens were found in these pts. PRO131921 had no MTD in this study. The most common adverse events were infusionrelated reactions, limited mostly to the first infusion.

Table 2 Third Generation CD20 monoclonal antibodies

\begin{tabular}{|c|c|c|c|c|c|c|}
\hline Monoclonal Ab & lg type & Patients & Regimen & $\begin{array}{l}\text { Overall response } \\
\text { rate }\end{array}$ & Adverse events & Reference \\
\hline \multirow[t]{3}{*}{$\begin{array}{l}\text { Obinutuzumab } \\
\text { (GA-101) }\end{array}$} & $\lg G 1$ & 21 & $\begin{array}{l}\text { Obinutuzumab (Refractory B cell } \\
\text { NHL) } 1600 / 800 \text { mg } 400 / 400 \text { mg }\end{array}$ & $60 \% 35 \%$ & $\begin{array}{l}\text { Infusion related reaction, neutropenia, } \\
\text { anemia, thrombocytopenia, tumor lysis } \\
\text { syndrome }\end{array}$ & {$[49]$} \\
\hline & & 28 & $\begin{array}{l}\text { G-CHOP (Relapsed or refractory FL) } \\
\text { 1600/800 mg 400/400 mg }\end{array}$ & $94 \%$ & $\begin{array}{l}\text { Infusion related reaction, neutropenia, } \\
\text { neuropathy, infection }\end{array}$ & {$[50]$} \\
\hline & & 28 & $\begin{array}{l}\text { G-FC (Relapsed or refractory FL) } \\
1600 / 800 \text { mg 400/400 mg }\end{array}$ & $93 \%$ & $\begin{array}{l}\text { Infusion related reaction, neutropenia, } \\
\text { rash, infection }\end{array}$ & {$[50]$} \\
\hline PRO131921 & $\operatorname{lgG1}$ & 24 & $\begin{array}{l}\text { PRO131921 (Relapsed/refractory B } \\
\text { cell NHL) } 25 \text { to } 800 \mathrm{mg} / \mathrm{m}^{2}\end{array}$ & $27 \%$ & $\begin{array}{l}\text { Infusion related reaction, upper } \\
\text { respiratory tract infection, neutropenia }\end{array}$ & {$[51]$} \\
\hline $\begin{array}{l}\text { Ocaratuzumab } \\
\text { (AME-133v) }\end{array}$ & $\operatorname{lgG1}$ & 56 & $\begin{array}{l}\text { Ocaratuzumab (Relapsed/Refractory } \\
\mathrm{FL} \text { ) } 100 \mathrm{mg} / \mathrm{m}^{2} 375 \mathrm{mg} / \mathrm{m}^{2}\end{array}$ & $36 \%$ & $\begin{array}{l}\text { Infusion related reaction, nasopharyngitis, } \\
\text { asthenia, lymphopenia, infection }\end{array}$ & {$[48]$} \\
\hline
\end{tabular}


Dose limiting toxicity (DLT) included a significant infusion reaction and grade 3 joint pain and fatigue after 2 infusions. There was a correlation between drug exposure and tumor shrinkage $(\mathrm{p}=0.049)$ as well as clinical response $(\mathrm{p}=0.034)$. This suggested that drug clearance (e.g. by tumor in excess of drug) is proportional to clinical efficacy. Twenty two of the 24 pts were evaluable at the time of report in 2009. There were 6 partial response (PR 27\%), 13 stable disease (SD), and 3 disease progression (PD). Half of 10 pts in the two highest dose cohorts responded. Further clinical trials are underway.

GA101 (RO5072759, obinutuzumab) is a fully humanized, type II, IgG1 mAb derived from humanization of the parental B-Ly1 mouse antibody and subsequent glycoengineering of Fc region [54-57]. GA101 binds CD20 through a totally different orientation than rituximab and over a larger epitope. It appears to have more potent activity through direct killing as well as NK-cell mediated ADCC effect. GA101 was shown to have activity in RTX-resistant cell lines [58,59].

In an open label multicenter, phase I/II study, GA101 was evaluated in patients with relapsed /refractory CD20 $+\mathrm{NHL} / \mathrm{CLL}[60]$. In the non-randomized dose-escalating phase I ( $3+3$ design), 21 patients were treated with GA101 (50-2,000 mg) on days 1 and 8 of cycle 1, and day 1 in cycles $2-8$ (21-day cycles). ORR was $56 \%$ $(\mathrm{CR}=31 \%, \mathrm{PR}=25 \%)$. In the phase II part of the study, patients with indolent NHL were randomized to one of two doses: $1,600 / 800 \mathrm{mg}(\mathrm{n}=22$, ORR $60 \%)$, or $400 / 400$ $\mathrm{mg}(\mathrm{n}=18$, ORR $35 \%)$. The median follow-up time was 23.1 months. The median PFS for patients with FL was 11.8 months for the high-dose cohort, and 6.0 months for the low dose cohort (HR: 0.77 [95\% CI 0.34-1.77). The most common adverse events (AE) were infusionrelated reactions (400/400 mg: 72\%; 1,600/800 mg: 73\%). Responses were also seen among the 5 patients who were retreated with GA101. PK data from the studies have suggested that responding patients metabolize GA101 more slowly than non-responders [61].

Obinutuzumab (GA101) in combination with cyclophosphamide /doxorubicin /vincristine /prednisone (G$\mathrm{CHOP}$ ) or fludarabine/cyclophosphamide (G-FC) has been studied in patients with $\mathrm{CD} 20+$ relapsed/refractory FL in an open-label, multicenter, randomized Phase Ib study (BO21000). Response rates were 94\% for G-CHOP and $93 \%$ for G-FC. Serum levels of GA101 from these pts receiving combination chemotherapies were measured by ELISA. GA101 PK data were reported [50]. The serum concentrations of GA101 corresponded to the GA101 dose level that pts received, regardless of chemotherapy arm.

GA101 represents the first third-generation type II glycoengineered CD20 mAb which entered randomized phase II/III clinical trials. GA101 was compared to RTX in a randomized phase II study in CLL/NHL patients [62]. In this study, a total of 175 pts (149 FL) were randomized to receive 4 weekly infusions of either GA101 (1000 mg, $\mathrm{n}=87)$ or rituximab $\left(375 \mathrm{mg} / \mathrm{m}^{2}, \mathrm{n}=88\right)$. Maintenance treatment with GA101 or rituximab every 2 months for up to 2 years at the same dose was given to responders. ORR was the primary endpoint in the FL population. In this population, ORR for GA101 was 43.2 $(32 / 74)$ v $38.7(29 / 75)$ for rituximab. The CR/CRu rate was 10.8 in the GA101 arm $v 6.7$ for rituximab. Therefore, this first head to head trial of GA101 against RTX demonstrated higher ORR and similar adverse events. Phase III trials of GA101 in combination with chemotherapy are ongoing.

\section{Conclusions and future directions}

Although RTX and newer mAbs against CD20 have revolutionized lymphoma therapy, a significant population of patients still succumbs to lymphomas. Novel agents with different mechanism of actions are being explored [63-76]. Bortezomib is an active agent for refractory mantle cell and other lymphomas [77-85]. Lenalidomide, an immunomodulatory agent, has been studied for lymphoma therapy $[67,86]$. mTOR inhibitors, everolimus and temsirolimus, are being studied for treatment of refractory and relapsed lymphomas [87-94]. New biomarkers, such as microRNAs, STATs and Tregs, appear to be useful for assisting lymphoma diagnosis and for developing new therapeutic agents [65,74,75,95-97]. Novel antibodies directed against lymphocyte-specific antigens, such as CD19 [98-101], CD22 [102-112], and CD30 [113-116], have shown promises for clinical applications. Combination regimens among these novel agents may provide further improvement on the outcome of lymphoma therapy.

Competing interest

The authors have no relevant conflicts of interest.

\section{Authors' contributions}

All authors have contributed to data preparation, drafting and revising the manuscripts. All authors have read and approved the final manuscript.

\section{Author details}

${ }^{1}$ Department of Oncology, People's Hospital, Henan Province, China. ${ }^{2}$ Department of Medicine, New York Medical College and Westchester Medical Center, Valhalla, NY 10595, USA.

Received: 26 September 2012 Accepted: 9 October 2012

Published: 11 October 2012

\section{References}

1. Coiffier B: Rituximab in the treatment of diffuse large B-cell lymphomas. Semin Oncol 2002, 29(1 Suppl 2):30-35.

2. Coiffier B: Rituximab in diffuse large B-cell lymphoma. Clin Adv Hematol Oncol 2004, 2(3):156-157.

3. Coiffier B: Rituximab and CHOP-like chemotherapy in good-prognosis diffuse large-B-cell lymphoma. Nature clinical practice Oncology 2006, 3(11):594-595. 
4. Coiffier B: Rituximab therapy in malignant lymphoma. Oncogene 2007 26(25):3603-3613.

5. Coiffier B, Lepage E, Briere J, Herbrecht R, Tilly H, Bouabdallah R, Morel P, Van Den Neste E, Salles G, Gaulard P, et al: CHOP chemotherapy plus rituximab compared with $\mathrm{CHOP}$ alone in elderly patients with diffuse large-B-cell lymphoma. N Engl J Med 2002, 346(4):235-242.

6. Mishima Y, Terui Y, Yokoyama M, Nishimura N, Sakajiri S, Ueda K, Kuboki Y Nakano K, Suzuki K, Nara E, et al: R-CHOP with dose-attenuated radiation therapy could induce good prognosis in gastric diffuse large $B$ cell lymphoma. Experimental Hematology \& Oncology 2012, 1(1):30.

7. Alduaij W, Illidge TM: The future of anti-CD20 monoclonal antibodies: are we making progress? Blood 2011, 117(11):2993-3001.

8. Alduaij W, Ivanov A, Honeychurch J, Cheadle EJ, Potluri S, Lim SH, Shimada K, Chan CH, Tutt A, Beers SA, et al: Novel type II anti-CD20 monoclonal antibody (GA101) evokes homotypic adhesion and actin-dependent, lysosome-mediated cell death in B-cell malignancies. Blood 2011, 117(17):4519-4529.

9. Tedder TF, Engel P: CD20: a regulator of cell-cycle progression of $B$ lymphocytes. Immunol Today 1994, 15(9):450-454.

10. Goldenberg DM, Morschhauser F, Wegener WA: Veltuzumab (humanized anti-CD20 monoclonal antibody): characterization, current clinical results, and future prospects. Leuk Lymphoma 2010, 51(5):747-755.

11. Uchiyama S, Suzuki Y, Otake K, Yokoyama M, Ohta M, Aikawa S, Komatsu M, Sawada T, Kagami Y, Morishima Y, et al: Development of novel humanized anti-CD20 antibodies based on affinity constant and epitope. Cancer Sci 2010, 101(1):201-209.

12. Robak T, Robak E: New anti-CD20 monoclonal antibodies for the treatment of B-cell lymphoid malignancies. BioDrugs : clinical immunotherapeutics, biopharmaceuticals and gene therapy 2011, 25(1):13-25.

13. Jaglowski SM, Alinari L, Lapalombella R, Muthusamy N, Byrd JC: The clinical application of monoclonal antibodies in chronic lymphocytic leukemia. Blood 2010, 116(19):3705-3714.

14. Honeychurch J, Alduaij W, Azizyan M, Cheadle EJ, Pelicano H, Ivanov A, Huang P, Cragg MS, Illidge TM: Antibody-induced nonapoptotic cell death in human lymphoma and leukemia cells is mediated through a novel reactive oxygen species-dependent pathway. Blood 2012, 119(15):3523-3533.

15. Czuczman MS, Gregory SA: The future of CD20 monoclonal antibody therapy in B-cell malignancies. Leukemia \& lymphoma 2010, 51(6):983-994.

16. Plosker GL, Figgitt DP: Rituximab: a review of its use in non-Hodgkin's lymphoma and chronic lymphocytic leukaemia. Drugs 2003, 63(8):803-843.

17. Coiffier B, Pfreundschuh M, Stahel R, Vose J, Zinzani PL: Aggressive lymphoma: improving treatment outcome with rituximab. Anticancer Drugs 2002, 13(Suppl 2):S43-50.

18. Pfreundschuh M, Trumper L, Osterborg A, Pettengell R, Trneny M, Imrie K, Ma D, Gill D, Walewski J, Zinzani P, et al: CHOP-like chemotherapy plus rituximab versus $\mathrm{CHOP}$-like chemotherapy alone in young patients with good-prognosis diffuse large-B-cell lymphoma: a randomised controlled trial by the MabThera International Trial (MInT) Group. Lancet Oncol 2006, 7(5):379-391.

19. Delaloye AB, Antonescu C, Louton T, Kuhlmann J, Hagenbeek A: Dosimetry of $90 \mathrm{Y}$-ibritumomab tiuxetan as consolidation of first remission in advanced-stage follicular lymphoma: results from the international phase 3 first-line indolent trial. J Nucl Med 2009, 50(11):1837-1843.

20. Esmaeli B, McLaughlin P, Pro B, Samaniego F, Gayed I, Hagemeister F, Romaquera J, Cabanillas F, Neelapu SS, Banay R, et al: Prospective trial of targeted radioimmunotherapy with Y-90 ibritumomab tiuxetan (Zevalin) for front-line treatment of early-stage extranodal indolent ocular adnexal lymphoma. Ann Oncol 2009, 20(4):709-714.

21. Friedberg JW, Fisher RI: lodine-131 tositumomab (Bexxar): radioimmunoconjugate therapy for indolent and transformed B-cell nonHodgkin's lymphoma. Expert Rev Anticancer Ther 2004, 4(1):18-26.

22. Buchegger F, Antonescu C, Helg C, Kosinski M, Prior JO, Delaloye AB, Press $\mathrm{OW}$, Ketterer N: Six of 12 relapsed or refractory indolent lymphoma patients treated 10 years ago with 1311-tositumomab remain in complete remission. J Nucl Med 2011, 52(6):896-900.

23. Corazzelli G, Frigeri F, Marcacci G, Capobianco G, Arcamone M, Becchimanzi C, Russo F, Pinto A: Rituximab plus gemcitabine, ifosfamide, oxaliplatin (R-GIFOX) as salvage therapy for recurrent Hodgkin lymphoma. ASCO Meeting Abstracts 2009, 27(15S):8579.
24. El Gnaoui T, Dupuis J, Belhadj K, Rahmouni A, Copie-Bergman C, Gaillard I, Divine M, Tabah-Fisch IM, Reyes F, Haioun C: Rituximab, gemcitabine and oxaliplatin (R-GEMOX): An effective regimen for relapsed and refractory B-cell lymphoma. ASCO Meeting Abstracts 2006, 24(18):7562.

25. Federico M, Luminari S, Dondi A, Sacchi S, Franco V, Pileri S, Lombardo M, Rossi G, Arcaini L, Chisesi T, et al: R-CVP versus R-CHOP versus R-FM as first-line therapy for advanced-stage follicular lymphoma: Final results of FOLL05 trial from the Fondazione Italiana Linfomi (FIL). ASCO Meeting Abstracts 2012, 30(15):8006

26. Recher C, Coiffier B, Haioun C, Molina TJ, Ferme C, Casasnovas O, Thieblemont C, Bosly A, Laurent G, Morschhauser F, et al: Intensified chemotherapy with ACVBP plus rituximab versus standard $\mathrm{CHOP}$ plus rituximab for the treatment of diffuse large B-cell lymphoma (LNH03-2B): an open-label randomised phase 3 trial. Lancet 2011, 378(9806):1858-1867.

27. Reynolds C, Di Bella N, Lyons RM, Hyman W, Richards DA, Robbins GJ, Vellek M, Boehm KA, Zhan F, Asmar L: A Phase III trial of fludarabine, cyclophosphamide, and rituximab vs. pentostatin, cyclophosphamide, and rituximab in B-cell chronic lymphocytic leukemia. Investigational new drugs 2012, 30(3):1232-1240.

28. Rummel MJ, Niederle N, Maschmeyer G, Banat AG, von Gruenhagen U, Losem C, Kofahl-Krause D, Heil G, Welslau M, Balser C, et al: Bendamustine plus rituximab (B-R) versus $\mathrm{CHOP}$ plus rituximab (CHOP-R) as first-line treatment in patients with indolent and mantle cell lymphomas $(\mathrm{MCL})$ : Updated results from the StiL NHL1 study. ASCO Meeting Abstracts 2012, 30(18):3.

29. Tilly H, Morschhauser F, Salles G, Casasnovas RO, Feugier P, Molina TJ, Jardin F, Terriou L, Haioun C, Coiffier B: Phase 1b study of lenalidomide in combination with rituximab-CHOP (R2-CHOP) in patients with B-cell lymphoma. Leukemia 2012, 26: http://www.ncbi.nlm.nih.gov/pubmed/22733106.

30. Tsimberidou AM, Wierda WG, Badoux X, Wen S, Plunkett W, O'Brien SM, Kipps TJ, Jones JA, Kantarjian H, Keating MJ: Evaluation of oxaliplatin, fludarabine, cytarabine, and rituximab (OFAR) combination therapy in aggressive chronic lymphocytic leukemia (CLL) and Richter's syndrome (RS). ASCO Meeting Abstracts 2010, 28(15):6521.

31. Tsimberidou AM, Wierda WG, Plunkett WK, O'Brien S, Lerner S, Smith SC, Kantarjian HM, Keating MJ: Phase I/II study of oxaliplatin, fludarabine, cytarabine, and rituximab in patients (OFAR2) with Richter's syndrome (RS), and relapsed or refractory B-cell chronic lymphocytic leukemia (CLL). ASCO Meeting Abstracts 2009, 27(15S):7031.

32. Baig NA, Taylor RP, Lindorfer MA, Church AK, Laplant BR, Pavey ES, Nowakowski GS, Zent CS: Complement dependent cytotoxicity in chronic lymphocytic leukemia: ofatumumab enhances alemtuzumab complement dependent cytotoxicity and reveals cells resistant to activated complement. Leuk Lymphoma 2012: http://www.ncbi.n/m.nih.gov/ pubmed/22475085 2012.

33. Coiffier B, Lepretre S, Pedersen LM, Gadeberg O, Fredriksen $H$, van Oers $M H$, Wooldridge J, Kloczko J, Holowiecki J, Hellmann A, et al: Safety and efficacy of ofatumumab, a fully human monoclonal anti-CD20 antibody, in patients with relapsed or refractory B-cell chronic lymphocytic leukemia: a phase 1-2 study. Blood 2008, 111(3):1094-1100.

34. Smolej L: Therapy of elderly/comorbid patients with chronic lymphocytic leukemia. Curr Pharm Des 2012, http://www.ncbi.nlm.nih.gov/pubmed/22591390.

35. Wierda WG, Kipps TJ, Durig J, Griskevicius L, Stilgenbauer S, Mayer J, Smolej L, Hess G, Griniute R, Hernandez-Ilizaliturri FJ, et al: Chemoimmunotherapy with O-FC in previously untreated patients with chronic lymphocytic leukemia. Blood 2011, 117(24):6450-6458

36. Wierda WG, Kipps TJ, Mayer J, Stilgenbauer S, Williams CD, Hellmann A, Robak T, Furman RR, Hillmen P, Trneny M, et al: Ofatumumab as single-agent CD20 immunotherapy in fludarabine-refractory chronic lymphocytic leukemia. J Clin Oncol 2010, 28(10):1749-1755.

37. Wierda WG, Padmanabhan S, Chan GW, Gupta IV, Lisby S, Osterborg A, Hx CDSI: Ofatumumab is active in patients with fludarabine-refractory CLL irrespective of prior rituximab: results from the phase 2 international study. Blood 2011, 118(19):5126-5129

38. Barth MJ, Hernandez-Ilizaliturri FJ, Mavis C, Tsai PC, Gibbs JF, Deeb G, Czuczman MS: Ofatumumab demonstrates activity against rituximabsensitive and -resistant cell lines, lymphoma xenografts and primary tumour cells from patients with B-cell lymphoma. Br J Haematol 2012, 156(4):490-498. 
39. Cheson BD: Ofatumumab, a novel anti-CD20 monoclonal antibody for the treatment of B-cell malignancies. J Clin Oncol 2010, 28(21):3525-3530.

40. Czuczman MS, Fayad L, Delwail V, Cartron G, Jacobsen E, Kuliczkowski K, Link BK, Pinter-Brown L, Radford J, Hellmann A, et al: Ofatumumab monotherapy in rituximab-refractory follicular lymphoma: results from a multicenter study. Blood 2012, 119(16):3698-3704.

41. Czuczman MS, Hess G, Gadeberg OV, Pedersen LM, Goldstein N, Gupta I, Jewell RC, Lin TS, Lisby S, Strange C, et al: Chemoimmunotherapy with ofatumumab in combination with $\mathrm{CHOP}$ in previously untreated follicular lymphoma. Br J Haematol 2012, 157(4):438-445.

42. Morschhauser F, Leonard JP, Fayad L, Coiffier B, Petillon MO, Coleman M, Schuster SJ, Dyer MJ, Horne H, Teoh N, et al: Humanized anti-CD20 antibody, veltuzumab, in refractory/recurrent non-Hodgkin's lymphoma: phase I/II results. J Clin Oncol 2009, 27(20):3346-3353.

43. Morschhauser F, Marlton P, Vitolo U, Linden O, Seymour JF, Crump M, Coiffier B, Foa R, Wassner E, Burger HU, et al: Results of a phase I/II study of ocrelizumab, a fully humanized anti-CD20 mAb, in patients with relapsed/refractory follicular lymphoma. Ann Oncol 2010, 21(9):1870-1876.

44. Stein R, Qu Z, Chen S, Rosario A, Shi V, Hayes M, Horak ID, Hansen HJ, Goldenberg DM: Characterization of a new humanized anti-CD20 monoclonal antibody, IMMU-106, and Its use in combination with the humanized anti-CD22 antibody, epratuzumab, for the therapy of nonHodgkin's lymphoma. Clin Cancer Res 2004, 10(8):2868-2878.

45. Saleh MN, Liebman H, Bernstein ZP, Negrea OG, Bussel JB, Onyegbula AC, Farber CM, Abassi R, Cosgriff TM, Pennington K, et al: Subcutaneous Injections of Low-Dose Anti-CD20 Veltuzumab for Treatment of Relapsed Immune Thrombocytopenia (ITP). ASH Annual Meeting Abstracts 2009, 114(22):1322.

46. Tobinai K, Ogura M, Kobayashi Y, Uchida T, Watanabe T, Oyama T, Maruyama D, Suzuki T, Mori M, Kasai M, et al: Phase I study of LY2469298, an Fc-engineered humanized anti-CD20 antibody, in patients with relapsed or refractory follicular lymphoma. Cancer Sci 2011, 102(2):432-438.

47. Forero-Torres A, de Vos S, Pohlman BL, Pashkevich M, Cronier DM, Dang $\mathrm{NH}$, Carpenter SP, Allan BW, Nelson JG, Slapak CA, et al: Results of a phase 1 study of AME-133v (LY2469298), an Fc-engineered humanized monoclonal anti-CD20 antibody, in FcgammaRIlla-genotyped patients with previously treated follicular lymphoma. Clin Cancer Res 2012, 18(5):1395-1403.

48. Wayne JL, Ganjoo KN, Pohlman BL, De Vos S, Flinn IW, Dang NH, Mapara MY, Smith MR, O'Reilly AM, Marulappa SY, et al: Efficacy of ocaratuzumab (AME-133v) in relapsed follicular lymphoma patients refractory to prior rituximab. ASCO Meeting Abstracts 2012, 30(15):8081.

49. Salles G, Morschhauser F, Lamy T, Milpied N, Thieblemont C, Tilly H, Bieska G, Asikanius E, Carlile D, Birkett J, et al: Phase 1 study results of the type II glycoengineered humanized anti-CD20 monoclonal antibody obinutuzumab (GA101) in B-cell lymphoma patients. Blood 2012, 119(22):5126-5132

50. Carlile D, Meneses-Lorente G, Wassner-Fritsch E, Hourcade-Potelleret F, Wenger MK, Cartron G, Vitolo U, Radford J, Davies A, Morschhauser F: Pharmacokinetics of Obinutuzumab (GA101) in Patients with CD20+ Relapsed/Refractory Malignant Disease Receiving Concomitant Chemotherapy (Phase lb Study BO21000). ASH Annual Meeting Abstracts 2011, 118(21):3704

51. Friedberg JW, Vose J, Kahl BS, Brunvand M, Goy A, Kasamon Y, Brington B, Li J, Ho W, Cheson BD: A Phase I Study of PRO131921, a Novel Anti-CD20 Monoclonal Antibody in Patients with Relapsed/Refractory CD20+ Indolent NHL: Correlation Between Clinical Responses and AUC Pharmacokinetics. ASH Annual Meeting Abstracts 2009, 114:3472.

52. Kahl BS, Cheson BD, Friedberg JW: Clinical Roundtable Monograph: current treatment options for $\mathrm{NHL}$ patients refractory to standard therapy: recent data in single-agent and combination therapy. Clin Adv Hematol Oncol 2010, 8(5):1-16.

53. van Meerten $T$, Hagenbeek A: CD20-targeted therapy: the next generation of antibodies. Seminars in hematology 2010, 47(2):199-210.

54. Friess T, Gerdes C, Nopora A, Patre M, Preiss S, van Puijenbroek E, Schuell C, Bauer S, Umana P, Klein C: GA101, a Novel Humanized Type II CD20 Antibody with Glycoengineered Fc and Enhanced Cell Death Induction, Mediates Superior Efficacy in a Variety of NHL Xenograft Models in Comparison to Rituximab. ASH Annual Meeting Abstracts 2007, 110(11):2338.
55. Heinrich D, Weinkauf M, Hutter G, Decheva K, Zimmermann Y, Hiddemann W, Dreyling MH: Differential Regulation Patterns of Anti-CD20 Antibodies GA101 and Rituximab in Mantle Cell Lymphoma. ASH Annual Meeting Abstracts 2010, 116(21):1839.

56. Herting F, Bader S, Umana P, Klein C: Enhanced Activity of GA101, a Novel Type II, Glycoengineered CD20 Antibody, In Combination with Bendamustine or Fludarabine, and with the Bcl-2 Family Inhibitors ABT-737 or ABT-263. ASH Annual Meeting Abstracts 2010, 116(21):3915.

57. Umana P, Ekkehard M, Peter B, Gabriele K, Ursula P, Suter T, Grau R, Schmidt C, Herter S, Gerdes C, et al: GA101, a Novel Humanized Type II CD20 Antibody with Glycoengineered Fc and Enhanced Cell Death Induction, Exhibits Superior Anti-Tumor Efficacy and Superior Tissue B Cell Depletion In Vivo. ASH Annual Meeting Abstracts 2007, 110(11):2348.

58. Dalle S, Reslan L, Manquat SB, Herting F, Klein C, Umana P, Dumontet C: Compared Antitumor Activity of GA101 and Rituximab against the Human RL Follicular Lymphoma Xenografts in SCID Beige Mice. ASH Annual Meeting Abstracts 2008, 112(11):1585

59. Ysebaert L, Laprevotte E, Klein C, Laurent G, Fournie J-J, Quillet-Mary A Clinical and Biological Characteristics Associated with In Vitro Activity of Anti-CD20 Monoclonal Antibodies, Rituximab and GA101, Against Chronic Lymphocytic Leukemia Cells. ASH Annual Meeting Abstracts 2010, 116(21):2459.

60. Salles GA, Morschhauser F, Thieblemont C, Solal-Celigny P, Lamy T, Tilly H, Feugier P, Le Gouill S, Gyan E, Bouabdallah R, et al: Efficacy and Safety of Obinutuzumab (GA101) Monotherapy in Relapsed/Refractory Indolent Non-Hodgkin's Lymphoma: Results From a Phase I/II Study (BO20999). ASH Annual Meeting Abstracts 2011, 118(21):268.

61. Meneses-Lorente G, Carlile D, Birkett J, Wenger MK, Cartron G, Morschhauser F, Salles GA: Pharmacokinetics of R05072759 (GA101) In Patients with Relapsed/Refractory CD20+ Malignant Disease (Phase I/II Study BO20999). ASH Annual Meeting Abstracts 2010, 116(21):1833.

62. Sehn LH, Goy A, Offner FC, Martinelli G, Friedberg J, Lasserre SF, Fine G, Press OW: Randomized Phase II Trial Comparing GA101 (Obinutuzumab) with Rituximab in Patients with Relapsed CD20 Indolent B-Cell NonHodgkin Lymphoma: Preliminary Analysis of the GAUSS Study. ASH Annual Meeting Abstracts 2011, 118(21):269.

63. Batty N, Malouf G, Issa J: Histone deacetylase inhibitors as anti-neoplastic agents. Cancer Lett 2009, 280:192-200.

64. Brown JR, Sharman JP, Harb WA, Kelly KR, Schreeder MT, Sweetenham JW, Barr PM, Foran JM, Gabrilove JL, Kipps TJ, et al: Phase lb trial of AVL-292, a covalent inhibitor of Bruton's tyrosine kinase (Btk), in chronic lymphocytic leukemia (CLL) and B-non-Hodgkin lymphoma (B-NHL). ASCO Meeting Abstracts 2012, 30(15):8032.

65. Budhu A, Ji J, Wang X: The clinical potential of microRNAs. Journal of Hematology \& Oncology 2010, 3(1):37.

66. Byrd JC, Furman RR, Coutre SE, Burger JA, Blum KA, Sharman JP, Flinn IW, Grant BW, Heerema NA, Johnson AJ, et al: The Bruton's tyrosine kinase (BTK) inhibitor PCl-32765 (P) in treatment-naive (TN) chronic lymphocytic leukemia (CLL) patients (pts): Interim results of a phase Ib/II study. ASCO Meeting Abstracts 2012, 30(15):6507.

67. Chanan-Khan A, Cheson B: Lenalidomide for the treatment of B-cell malignancies. J Clin Oncol 2008, 26:1544-1552

68. Chang JE, Kahl BS: Bendamustine: more ammunition in the battle against mantle cell lymphoma. Leuk Lymphoma 2012, 53(7):1249-1250.

69. Elbaz H, Stueckle T, Tse W, Rojanasakul Y, Dinu C: Digitoxin and its analogs as novel cancer therapeutics. Experimental Hematology \& Oncology 2012, 1(1):4.

70. Ge X, Wang X: Role of Wnt canonical pathway in hematological malignancies. Journal of Hematology \& Oncology 2010, 3(1):33.

71. Johnson P: New targets for lymphoma treatment. Ann Oncol 2008 19(4):56-59.

72. Patrick J, Yuan R, Cavalli F, Thomas W: Targeted therapy of lymphoma. J Hematol Oncol 2010, 3:45.

73. Tan J, Cang S, Ma Y, Petrillo RL, Liu D: Novel histone deacetylase inhibitors in clinical trials as anti-cancer agents. J Hematol Oncol 2010, 3:5.

74. Turkson J: STAT proteins as novel targets for cancer drug discovery. Expert Opin Ther Targets 2004, 8(5):409-422.

75. Wu ZL, Song YQ, Shi YF, Zhu J: High nuclear expression of STAT3 is associated with unfavorable prognosis in diffuse large B-cell lymphoma. J Hematol Oncol 2011, 4(1):31. 
76. Yuan Y, Liao YM, Hsueh CT, Mirshahidi HR: Novel targeted therapeutics: inhibitors of MDM2. ALK and PARP. J Hematol Oncol 2011, 4:16.

77. Adams J, Palombella V, Sausville E, Johnson J, Destree A, Lazarus D, Maas J, Pien C, Prakash S, Elliott P: Proteasome inhibitors: a novel class of potent and effective antitumor agents. Cancer Res 1999, 59:2615-2622.

78. Belch A, Kouroukis C, Crump M, Sehn L, Gascoyne R, Klasa R, Powers J, Wright J, Eisenhauer E: A phase II study of bortezomib in mantle cell lymphoma: the National Cancer Institute of Canada Clinical Trials Group trial IND.150. Ann Oncol 2007, 18:116-121.

79. Blum K, Johnson J, Niedzwiecki D, Canellos G, Cheson B, Bartlett N: Single agent bortezomib in the treatment of relapsed and refractory Hodgkin lymphoma: cancer and leukemia Group B protocol 50206. Leuk Lymphoma 2007, 48:1313-1319.

80. Coiffier B, Osmanov EA, Hong X, Scheliga A, Mayer J, Offner F, Rule S, Teixeira A, Walewski J, de Vos $S$, et al: Bortezomib plus rituximab versus rituximab alone in patients with relapsed, rituximab-naive or rituximabsensitive, follicular lymphoma: a randomised phase 3 trial. Lancet Oncol 2011, 12(8):773-784.

81. Kahl B, Chang J, Eickhoff J, Gilbert L, Rogers E, Werndli J, Huie M, McFarland $T$, Volk M, Blank J, et al: VcR-CVAD produces a high response rate in untreated mantle cell lymphoma: a phase II study from the Wisconsin Oncology Network. Blood 2008, 112(Suppl 1):265.

82. Mendler J, Kelly J, Voci S, Marquis D, Rich L, Rossi R, Bernstein S, Jordan C, Liesveld J, Fisher R, et al: Bortezomib and gemcitabine in relapsed or refractory Hodgkin's lymphoma. Ann Oncol 2008, 19:1759-1764.

83. Mitsiades C, Mitsiades N, Hideshima T, Richardson P, Anderson K: Proteasome inhibition as a new therapeutic principle in hematological malignancies. Curr Drug Targets 2006, 7:1341-1347.

84. Trelle $S$, Sezer O, Naumann R, Rummel M, Keller U, Engert A, Borchmann P: Bortezomib in combination with dexamethasone for patients with relapsed Hodgkin's lymphoma: results of a prematurely closed phase II study (NCT00148018). Haematologica 2007, 92:568-569.

85. Weigert $\mathrm{O}$, Weidmann E, Mueck R, Bentz M, von Schilling C, Rohrberg R, Jentsch-Ullrich K, Hiddemann W, Dreyling M: A novel regimen combining high dose cytarabine and bortezomib has activity in multiply relapsed and refractory mantle cell lymphoma - long-term results of a multicenter observation study. Leuk Lymphoma 2009, 50:716-722.

86. Habermann T, Lossos I, Justice G, Vose J, Wiernik P, McBride K, Wride K, Ervin-Haynes A, Takeshita K, Pietronigro D, et al: Lenalidomide oral monotherapy produces a high response rate in patients with relapsed or refractory mantle cell lymphoma. Br J Haematol 2009, 145:344-349.

87. Altman J, Platanias L: Exploiting the mammalian target of rapamycin pathway in hematologic malignancies. Curr Opin Hematol 2008, 15:88-94.

88. Hess G, Herbrecht R, Romaguera J, Verhoef G, Crump M, Gisselbrecht C, Laurell A, Offner F, Strahs A, Berkenblit A, et al: Phase III study to evaluate temsirolimus compared with investigator's choice therapy for the treatment of relapsed or refractory mantle cell lymphoma. J Clin Oncol 2009, 27:3822-3829.

89. Johnston P, Inwards D, Colgan J, LaPlant B, Kabat B, Habermann T, Micallef I, Porrata L, Ansell S, Reeder C, et al: A phase II trial of the oral mTOR inhibitor everolimus in relapsed Hodgkin lymphoma. Am J Hematol 2010, 85:320-324.

90. Jundt F, Raetzel N, Muller C, Calkhoven C, Kley K, Mathas S, Lietz A, Leutz A, Dorken $B$ : A rapamycin derivative (everolimus) controls proliferation through down-regulation of truncated CCAAT enhancer binding protein beta and NF-\{kappa\}B activity in Hodgkin and anaplastic large cell lymphomas. Blood 2005, 106:1801-1807.

91. Teachey D, Grupp S, Brown V: Mammalian target of rapamycin inhibitors and their potential role in therapy in leukaemia and other haematological malignancies. Br J Haematol 2009, 145:569-580.

92. Witzig T, Geyer S, Ghobrial I, Inwards D, Fonseca R, Kurtin P, Ansell S, Luyun $R$, Flynn P, Morton $R$, et al: Phase II trial of single-agent temsirolimus (CCl-779) for relapsed mantle cell lymphoma. J Clin Oncol 2005, 23:5347-5356.

93. Yazbeck V, Buglio D, Georgakis G, Li Y, Iwado E, Romaguera J, Kondo S, Younes A: Temsirolimus downregulates p21 without altering cyclin D1 expression and induces autophagy and synergizes with vorinostat in mantle cell lymphoma. Exp Hematol 2008, 36:443-450.

94. Yee K, Zeng Z, Konopleva M, Verstovsek S, Ravandi F, Ferrajoli A, Thomas D, Wierda W, Apostolidou E, Albitar M, et al: Phase I/II study of the mammalian target of rapamycin inhibitor everolimus (RAD001) in patients with relapsed or refractory hematologic malignancies. Clin Cancer Res 2006, 12:5165-5173.

95. Chen Z, Han Z: STAT3: a critical transcription activator in angiogenesis Med Res Rev 2008, 28(2):185-200.

96. Ding B, Yu J, Yu R, Mendez L, Shaknovich R, Zhang Y, Cattoretti G, Ye B: Constitutively activated STAT3 promotes cell proliferation and survival in the activated B-cell subtype of diffuse large B-cell lymphomas. Blood 2008, 111(3):1515-1523.

97. Wang J, Ke XY: The four types of Tregs in malignant lymphomas. J Hematol Oncol 2011, 4:50

98. Al-Katib AM, Aboukameel A, Mohammad R, Bissery MC, Zuany-Amorim C: Superior antitumor activity of SAR3419 to rituximab in xenograft models for non-Hodgkin's lymphoma. Clin Cancer Res 2009, 15(12):4038-4045.

99. Blanc V, Bousseau A, Caron A, Carrez C, Lutz RJ, Lambert JM: SAR3419: an anti-CD19-Maytansinoid Immunoconjugate for the treatment of B-cell malignancies. Clin Cancer Res 2011, 17(20):6448-6458.

100. Younes A, Kim S, Romaguera J, Copeland A, Farial Sde C, Kwak LW, Fayad L, Hagemeister F, Fanale M, Neelapu S, et al: Phase I Multidose-Escalation Study of the Anti-CD19 Maytansinoid Immunoconjugate SAR3419 Administered by Intravenous Infusion Every 3 Weeks to Patients With Relapsed/Refractory B-Cell Lymphoma. J Clin Oncol 2012, 30(22):2776-2782.

101. Coiffier B, Morschhauser F, Dupuis J, Haioun C, Laine F, Houot R, Tilly H, Brehar O, Lambert JM, Fagniez N, et al: Phase I study cohort evaluating an optimized administration schedule of SAR3419, an anti-CD19 DM4loaded antibody drug conjugate (ADC), in patients (pts) with CD19 positive relapsed/refractory b-cell non-Hodgkin's lymphoma (NCT00796731). ASCO Meeting Abstracts 2012, 30(15):8057.

102. Schweizer $A$, Wohner $M$, Prescher $H$, Brossmer $R$, Nitschke L: Targeting of CD22-positive B-cell lymphoma cells by synthetic divalent sialic acid analogues. Eur J Immunol 2012, 2012:2012. http://www.ncbi.nlm.nih.gov/pubmed/22777817.

103. Kantarjian $H$, Thomas D, Jorgensen J, Jabbour E, Kebriaei P, Rytting M, York S, Ravandi F, Kwari M, Faderl S, et al: Inotuzumab ozogamicin, an antiCD22-calecheamicin conjugate, for refractory and relapsed acute lymphocytic leukaemia: a phase 2 study. The lancet oncology 2012, 13(4):403-411.

104. Hoelzer D: Anti-CD22 therapy in acute lymphoblastic leukaemia. The lancet oncology 2012, 13(4):329-331.

105. Kreitman RJ, Tallman MS, Robak T, Coutre S, Wilson WH, Stetler-Stevenson M, Fitzgerald DJ, Lechleider R, Pastan I: Phase I trial of anti-CD22 recombinant immunotoxin moxetumomab pasudotox (CAT-8015 or HA22) in patients with hairy cell leukemia. Journal of clinical oncology official journal of the American Society of Clinical Oncology 2012, 30(15):1822-1828.

106. Ogura M, Hatake K, Ando K, Tobinai K, Tokushige K, Ono C, Ishibashi T, Vandendries E: Phase I study of anti-CD22 immunoconjugate inotuzumab ozogamicin plus rituximab in relapsed/refractory B-cell non-Hodgkin lymphoma. Cancer science 2012, 103(5):933-938.

107. Sharkey RM, Govindan SV, Cardillo TM, Goldenberg DM: Epratuzumab-SN38: a new antibody-drug conjugate for the therapy of hematologic malignancies. Molecular cancer therapeutics 2012, 11(1):224-234.

108. Ma H, Qazi S, Ozer Z, Gaynon P, Reaman GH, Uckun FM: CD22 Exon 12 deletion is a characteristic genetic defect of therapy-refractory clones in paediatric acute lymphoblastic leukaemia. British journal of haematology 2012, 156(1):89-98

109. de Vries JF, Zwaan CM, De Bie M, Voerman JS, den Boer ML, van Dongen JJ, van der Velden $\mathrm{VH}$ : The novel calicheamicin-conjugated CD22 antibody inotuzumab ozogamicin (CMC-544) effectively kills primary pediatric acute lymphoblastic leukemia cells. Leukemia : official journal of the Leukemia Society of America, Leukemia Research Fund, UK 2012, 26(2):255-264

110. Chen WC, Sigal DS, Saven A, Paulson JC: Targeting B lymphoma with nanoparticles bearing glycan ligands of CD22. Leukemia \& lymphoma 2012, 53(2):208-210

111. Biberacher V, Decker T, Oelsner M, Wagner M, Bogner C, Schmidt B, Kreitman RJ, Peschel C, Pastan I, Meyer Zum Buschenfelde C, et al: The cytotoxicity of anti-CD22 immunotoxin is enhanced by bryostatin 1 in B-cell lymphomas through CD22 upregulation and PKC-betall depletion. Haematologica 2012, 97(5):771-779. 
112. Sikder MA, Friedberg JW: Beyond rituximab: The future of monoclonal antibodies in B-cell non-Hodgkin lymphoma. Curr Hematol Malig Rep 2008, 3(4):187-193.

113. Gualberto A: Brentuximab Vedotin (SGN-35), an antibody-drug conjugate for the treatment of CD30-positive malignancies. Expert Opin Investig Drugs 2012, 21(2):205-216.

114. Nathwani N, Krishnan AY, Huang Q, Kim Y, Karanes C, Smith EP, Forman SJ, Sievers $\mathrm{E}$, Thomas SH, Chen RW: Persistence of CD30 expression in Hodgkin lymphoma following brentuximab vedotin (SGN-35) treatment failure. Leuk Lymphoma 2012

http://www.ncbi.nlm.nih.gov/pubmed/22369501.

115. Okeley NM, Miyamoto JB, Zhang X, Sanderson RJ, Benjamin DR, Sievers EL, Senter PD, Alley SC: Intracellular activation of SGN-35, a potent anti-CD30 antibody-drug conjugate. Clin Cancer Res 2010, 16(3):888-897.

116. Younes A, Bartlett NL, Leonard JP, Kennedy DA, Lynch CM, Sievers EL, Forero-Torres A: Brentuximab vedotin (SGN-35) for relapsed CD30-positive lymphomas. N Engl J Med 2010, 363(19):1812-1821.

doi:10.1186/1756-8722-5-64

Cite this article as: Cang et al:: Novel CD20 monoclonal antibodies for lymphoma therapy. Journal of Hematology \& Oncology 2012 5:64.

\section{Submit your next manuscript to BioMed Central and take full advantage of:}

- Convenient online submission

- Thorough peer review

- No space constraints or color figure charges

- Immediate publication on acceptance

- Inclusion in PubMed, CAS, Scopus and Google Scholar

- Research which is freely available for redistribution 